\title{
Free Radical Scavenging Activity and Biochemical characteristics of Ulva rigida (Ulvophyceae) and Arthrospira platensis (Cyanophyceae) ${ }^{\#}$
}

\author{
İlknur Ak ${ }^{1, a, *}$, Gülen Türker ${ }^{2, b}$ \\ ${ }^{1}$ Department of Aquaculture, Faculty of Marine Sciences and Technology, Çanakkale Onsekiz Mart University, 17100, Çanakkale, Turkey. \\ ${ }^{2}$ Department of Food Technology, Çanakkale School of Applied Sciences, Çanakkale Onsekiz Mart University, 17100 Çanakkale, Turkey \\ ${ }^{*}$ Corresponding author

\begin{tabular}{|c|c|}
\hline A R T ICLE INFO & A B S T R A C T \\
\hline $\begin{array}{l}\text { "This study was presented as an oral } \\
\text { presentation at the 4th International } \\
\text { Anatolian Agriculture, Food, } \\
\text { Environment and Biology Congress } \\
\text { (Afyonkarahisar, TARGID 2019) } \\
\text { Research Article } \\
\text { Received : } 30 / 06 / 2019 \\
\text { Accepted : 04/09/2019 }\end{array}$ & $\begin{array}{l}\text { In this study, the antioxidant activities and biochemical characteristics of Ulva rigida (Ulvophyceae) } \\
\text { and Arthrospira platensis (Cyanophyceae) were determined. The extracts from two seaweed species } \\
\text { were evaluated for their free radical scavenging activity, using the } 1,1 \text {-diphenyl-2-picrylhydrazyl } \\
\text { hydrate (DPPH) method, their total phenolic, flavonoid, and condensed tannin contents, through } \\
\text { Folin-Ciocalteu, Quettier-Deleu, and Price methods, respectively. The extracts of two seaweeds } \\
\text { showed a low free radical scavenging capacity in comparison with commercial antioxidant BHT } \\
\text { (butylated hydroxytoluene), and vitamin C. The extract of } U \text {. rigida demonstrated greater antioxidant } \\
\text { potential with a low } \mathrm{IC}_{50}(3.76 \pm 0.02 \mathrm{mg} / \mathrm{g} \text { Ext.). The total phenolic contents were ranged from } \\
2.21 \pm 0.08(U \text {. rigida) to } 8.59 \pm 0.62(A . \text { platensis) } \mathrm{mg} \mathrm{GAE} / \mathrm{g} \text { of extract. The highest flavonoid } \\
\text { content was found in } A . p l a t e n s i s \text { as } 22.70 \pm 0.65 \mathrm{mg} \text { rutin } / \mathrm{g} \text { of extract. The contents of condensed } \\
\text { tannin were measured } 3.01 \pm 0.11 \mathrm{mg} \mathrm{CE} / \mathrm{g} \text { of extract for } A \text {. platensis and } 3.76 \pm 0.06 \mathrm{mg} \mathrm{CE} / \mathrm{g} \text { of } \\
\text { extract for } U \text {. rigida. According to results obtained, } U \text {. rigida and } A \text {. maxima possess antioxidant } \\
\text { activity and could be used in for future applications in medicine, functional foods, and agriculture. }\end{array}$ \\
\hline
\end{tabular}

Flavonoids

Phenolics

Tannins

\section{Introduction}

Algae are known to possess an expansive range of physiological and biochemical properties and that can be harnessed for commercial applications such as food, pharmaceutical, cosmeceutical, biochemical, and bioenergy production (Kumar et al., 2019). They also contain bioactive substances like polysaccharides, proteins, lipids, and polyphenols, with antioxidant, antibacterial, antiviral and antifungal properties and this gives them great potential as a supplement in functional food or for the extraction of compounds (Yuan et al., 2005; Kumar et al. 2008; Ak and Türker, 2018).

Antioxidants are substances that at low concentrations delay the oxidative stress, DNA mutations, malignant transformations, as well as other parameters of cell damage (Sindhi et al., 2013; Pisoschi and Pop, 2015). They neutralize free radicals and protect the body from free radicals by maintaining redox balance (Pisoschi and Pop,
2015). Phenolic compounds or polyphenols are considered as one of the most important classes of natural antioxidants (Duan et al., 2006). Moreover, they can be divided into several classes, such as phenolic acids, flavonoids, isoflavonoids, stilbenes, lignans, and phenolic polymers (condensed tannins and hydrolysable tannins) (Manach et al., 2004). Polyphenols can behave as reactive oxygen species (ROS) and they can inhibit lipid oxidation with chelating metal ions (Rodrigo and Bosco, 2006).

Interest in new sources of natural antioxidants has increased in recent years in order to reduce the use of synthetic forms (Cox et al., 2010). Synthetic antioxidants, such as butylated hydroxytoluene (BHT) or butylated hydroxyanisole (BHA), generally are used. However, it is suspected that they are responsible for several side effects, such as carcinogenesis and liver damage (Alenisan et al., 2017; Shalaby, 2015). Consequently, alternatives to 
artificial antioxidants are increasingly demanded (Vasconcelos et al., 2018). Antioxidants from plant origin also can retard or alleviate the extent of oxidative deterioration and increase the shelf life of foods (Cox et al., 2010; Choe, 2017). Commercially available natural antioxidants are mostly derived from terrestrial plants (Goiris et al., 2012). However, recent studies showed that micro and macro algae are an alternative source of natural antioxidants (Wang et al., 2007; Cox et al., 2010; Goiris et al., 2012; Jensen et al., 2015; Ak and Türker, 2018; Kumar et al., 2019). Algae and their and their secondary metabolites like various phenolic and pigment components and polysaccharides offer the opportunity in this respect (Matanjun et al., 2008; Jerez-Martel et al., 2017; Ismail, 2017). A strategic extraction of these metabolites from algae would increase the potential for new discoveries targeting high value-added products (Trigui et al. 2013).

Ulva sp., a green macroalga is common in the coast of Mediterranean. It is a good candidate for culture due to its nutritional value and high protein content (Gordillo et al., 2001; Peña-Rodríguez et al., 2011; Ak et al., 2015). Because of their protein levels, Ulva species are used as vegetables for human nutrition, especially in Asian countries (Fleurence, 1999). Moreover, Ulva species also contains minerals, fats, and phytochemicals (Kazir et al., 2019). Arthrospira sp., is a free-floating filamentous cyanobacterium that has received considerable attention for its high protein content and high concentrations of phenolic acids, essential fatty acids, vitamins (such as tocopherols and $\mathrm{B}_{1}, \mathrm{~B}_{2}, \mathrm{~B}_{6}, \mathrm{~B}_{12}, \mathrm{E}$ and $\left.\mathrm{D}\right)$, minerals and other constituents which have antioxidants activity (Vonshak, 1997; Wang et al., 2007; Jensen et al., 2015).

The main objective of this study was to determine the antioxidant activity and biochemical characteristics of extracts obtained from Arthrospira platensis (Cyanophyceae) and Ulva rigida (Ulvophyceae) with regard to their potential uses. We also used Pearson's correlation to estimate and compare the contribution of polyphenolic compounds to the measured antioxidant activities.

\section{Materials and Methods}

\section{Chemicals}

All chemicals were purchased from Fluka Chemie (Switzerland), Merck (Germany), Sigma-Aldrich (USA), and SPA (Milan, Italy). All reagents used were of analytical grade.

\section{Algae Samples}

Ulva rigida collected quantitatively by hand from intertidal zones at three locations in the Dardanelles (Çanakkale) Strait (40 6' $\left.43^{\prime \prime} \mathrm{N}, 26^{\circ} 24^{\prime} 15^{\prime \prime} \mathrm{E}\right)$. The Dardanos and Kepez, areas were chosen as sampling areas where Ulva species were distributed intensively. The macro alga material was identified according to Guiry and Guiry (2019). The samples were cleaned from their epiphytes, dried at $30^{\circ} \mathrm{C}$ and milled into powder before extraction.

Arthrospira platensis was supplied from the Algae Culture Collection in the Department of Aquaculture, Ege University (İzmir, Turkey). The cultures were grown in 50 L polyethylene bags with Zarrouk (1966) medium.
Cultures were continuously aerated with a blower at 29 $\pm 2^{\circ} \mathrm{C}$ and illuminated with fluorescent lamps $100 \mu \mathrm{mol}$ photons $\mathrm{m}^{-2} \mathrm{~s}^{-1}$ photon flux density. Biomass samples were harvested and dried at $30^{\circ} \mathrm{C}$ before extractions were carried out.

\section{DPPH Free Radical Scavenging Activity Assay}

DPPH (1,1-diphenyl-2-picrylhydrazyl) radical scavenging activity was determined according to the Brand-Williams et al. (1995). Each sample was diluted in methanol prior to the analysis $(1 \mathrm{mg} / \mathrm{ml})$. An aliquot $(0.1$ $\mathrm{mL}$ ) of the solution was added to $3.9 \mathrm{~mL}$ of DPPH solution $\left(6 \times 10^{-5} \mathrm{M}\right.$ in methanol), thoroughly mixed, and the absorbance of the sample at $515 \mathrm{~nm}$ was recorded after the time necessary for the reaction to reach a plateau. The absorbance of DPPH solution in methanol, without any antioxidant (control), was also measured. The percentage of DPPH radical scavenging (\%) activity was calculated by the following equation:

$$
\mathrm{DPPH}=\left[\left(\mathrm{A}_{\text {control }}-\mathrm{A}_{\text {sample }}\right) / \mathrm{A}_{\text {control }}\right] \times 100
$$

where A sample is the absorbance of the sample after the time necessary to reach the plateau $(30 \mathrm{~min})$ and $A$ control is the absorbance of DPPH. Butylated hydroxytoluene (BHT), $\alpha$ tocopherol, and Vitamin C were used as positive controls. Extract concentrations providing $\mathrm{IC}_{50}$ inhibition values were calculated from graph plotting using nonlinear regression.

\section{Determination of Total Phenolic Contents}

The total phenolic content of algae was measured using Folin-Ciocalteu reagent according to Djeridane et al. (2006). The gallic acid was used as a standard and a standard curve was drawn. Different concentrations of gallic acid were prepared in $80 \%$ of methanol, and their absorbance was measured at $765 \mathrm{~nm}$. The seaweed samples were dissolved with the Folin-Ciocalteu. The solutions were incubated at room temperature for $1 \mathrm{~min}$ and $20 \%$ sodium carbonate solution was added. The mixture was shaken vigorously and then it was incubated for $2 \mathrm{~h}$ in the dark at room temperature. The absorbance of all samples was measured at $760 \mathrm{~nm}$ using UV-Vis spectrophotometer (Thermo Aquamate). The results are expressed in $\mathrm{mg}$ of gallic acid per g (GEA) of extract.

\section{Determination of Total Flavonoid Contents}

The total flavonoid content was determined according to Quettier- Deleu et al. (2000). Briefly, $1 \mathrm{ml}$ of methanolic extract solution was added to $1 \mathrm{ml}$ of $2 \%$ methanolic $\mathrm{AlCl}_{3}$, $6 \mathrm{H}_{2} \mathrm{O}$. Following thorough mixing of the solution, the absorbance against blank was determined at $430 \mathrm{~nm}$ after 10 min later. Rutin was used to prepare the standard curve and results were expressed as $\mathrm{mg}$ rutin/ $\mathrm{g}$ extract.

\section{Determination of Condensed Tannin Contents}

Condensed tannin content was evaluated according to Price et al., (1978). $20 \mathrm{ml}$ of $1 \% \mathrm{HCl}$ in methanol was added to an aliquot of $0.5 \mathrm{~g}$ of the seaweed extracts. Then, the samples placed in a water bath at $30^{\circ} \mathrm{C}$ with constant shaking for $20 \mathrm{~min}$. and then they were centrifuged. Aliquots of the supernatants were placed in two separate assay tubes, one for the sample determination and the other 
for blank determination. Samples and blanks were incubated for exactly $20 \mathrm{~min}$ after adding $5 \mathrm{ml}$ of the vanillin reagent to the samples and $4 \% \mathrm{HCl}$ in methanol to the blanks. The absorbance against blank was read at $500 \mathrm{~nm}$ using a UV-Vis spectrophotometer (Thermo Aquamate). The catechin was used to prepare the standard curve and results were expressed as $\mathrm{mg}$ catechin equivalents per gram of extract $(\mu \mathrm{g} \mathrm{CE} / \mathrm{g})$.

\section{Statistical Analysis}

The significance of difference was calculated by Student's $t$-test or one-way analysis of variance (ANOVA). Before Student's $t$-test or ANOVA, all data were checked for homogeneity of variance and normal distribution. Pearson's correlation analysis was used to assess correlations between means. A significant difference was considered at the level of $\mathrm{P}<0.05$.

\section{Results and Discussion}

DPPH reagent has been used for investigating the free radical scavenging activities of compounds (Cox et al., 2010). The scavenging activity of $U$. rigida and $A$. platensis on DPPH free radical are summarized in Table 1. $U$. rigida showed the highest antioxidant potential with a low $\mathrm{IC}_{50}(3.76 \pm 0.02 \mathrm{mg} / \mathrm{g}$ Ext.) and significantly lower than three commercial antioxidants tested, BHT, $\alpha$ tocopherol and Vitamin $\mathrm{C}$, respectively. The antioxidant activities of two algae were significantly different $(\mathrm{P}<0.05)$, and Inhibition \% values ranged from $36.46 \pm 0.09$ to $41.40 \pm 0.05 \mathrm{mg} / \mathrm{g}$ of extract. Thus, both $U$. rigida and $A$. platensis showed medium potential DPPH radical scavenging activity.

The phenolic compounds belonging to the flavonoid, phenolic acids, and tannin groups are recognized as the dominant contributors to the antioxidant capacity (Duan et al., 2006; Rodrigo and Bosco, 2006). Many studies showed that those phenolic compounds are one of the most effective antioxidants in algae (Duan et al., 2006; Cox et al., 2010; Goiris et al., 2012; Jensen et al., 2015). The total phenolic contents of extracts of two algae are presented in Table 2. The total phenolic content of samples ranged from $2.21 \pm 0.08$ to $8.59 \pm 0.62 \mathrm{mg} / \mathrm{g}$ GAE of extract. Blue-green alga $A$. platensis exhibited highest total phenolic content, as compared to a green alga, $U$. rigida. Liu et al. (2011) and Gargouri et al. (2016) reported that blue-green algae extracts had a phenolic content of 2.49 to $19.47 \mathrm{mg} / \mathrm{g} \mathrm{GAE}$ of extract. The total phenolic contents of A. platensis of this study are among these values. Flavonoids, the largest group of phenolic compounds and they show antioxidant mechanisms by metal chelation and by inhibiting lipoxygenase (Goiris et al., 2012). They are important in plant defense mechanisms against the stressed environmental conditions such as excessive light or ultraviolet (UV) radiation and pollutants (Mierziak et al., 2014). The total flavonoid content of two algae changed from $12.61 \pm 0.07$ to $22.70 \pm 0.65 \mathrm{mg} / \mathrm{g}$ of extract (Table 2 ). The total flavonoid content of $A$. platensis was significantly higher than $U$. rigida $(\mathrm{P}<0.05)$. Klejdus et al. (2009) stated that phenolic compounds were more abundant in microalgae compared to cyanobacteria species. However, several studies showed that cyanobacteria species could produce a great variety of secondary bioactive metabolites (Plaza et al., 2009; Shalaby 2015). Tannins are secondary plant metabolites and are widespread among terrestrial and marine plants (Mueller-Harvey, 2006; Zubek et al., 2012). The total condensed tannin content of algae extracts of $U$. rigida and A. platensis can be seen in Table 2. Condensed tannins of the studied algae changed from $3.01 \pm 0.11$ to $3.76 \pm 0.06 \mathrm{mg}$ $\mathrm{CE} / \mathrm{g}$ of extract. $U$. rigida contained significantly higher total condensed tannin contents $(\mathrm{P}<0.05)$. According to Cox et al. (2010) and Gargouri et al. (2016) condensed tannins found in blue-green and green algae an in lower amounts in brown and red algae. Our results show a similarity with these studies.

Table 1 The DPPH radical scavenging activities of $U$. rigida and A. platensis. Different lowercase letters show the significant differences between the groups according to the ANOVA results $(\mathrm{P}<0.05)$.

\begin{tabular}{l|cc}
\hline \multicolumn{1}{c|}{ Species } & $\mathrm{IC}_{50}$ inhibition values $(\mathrm{mg} / \mathrm{g}$ Ext.) & Inhibition \% \\
\hline U. rigida & $3.76 \pm 0.02^{\mathrm{b}}$ & $41.40 \pm 0.05^{\mathrm{b}}$ \\
A. platensis & $3.89 \pm 0.07^{\mathrm{a}}$ & $36.46 \pm 0.09^{\mathrm{c}}$ \\
Butylated hydroxytoluene & $1.33 \pm 0.01^{\mathrm{d}}$ & $99.00 \pm 0.11^{\mathrm{a}}$ \\
$\alpha$-tocopherol & $1.48 \pm 0.02^{\mathrm{c}}$ & $96.00 \pm 0.15^{\mathrm{a}}$ \\
Vitamin C & $1.35 \pm 0.02^{\mathrm{d}}$ & $98.00 \pm 0.10^{\mathrm{a}}$ \\
\hline
\end{tabular}

Table 2 The total phenolic, flavonoid, and condensed tannin of $U$. rigida and A. platensis. Different lowercase letters show the significant differences between the groups according to the Student's $t$-test results $(\mathrm{P}<0.05)$.

\begin{tabular}{l|ccc}
\multicolumn{1}{c|}{ Species } & $\begin{array}{c}\text { Total Phenolic } \\
\text { (mg/g GAE Ext.) }\end{array}$ & $\begin{array}{c}\text { Total Flavonoid } \\
\text { (mg/g Ext.) }\end{array}$ & $\begin{array}{c}\text { Condensed Tannin } \\
\text { (mg CE/g Ext.) }\end{array}$ \\
\hline U. rigida & $2.21 \pm 0.08^{\mathrm{b}}$ & $12.61 \pm 0.07^{\mathrm{b}}$ & $3.76 \pm 0.06^{\mathrm{a}}$ \\
A. platensis & $8.59 \pm 0.62^{\mathrm{a}}$ & $22.70 \pm 0.65^{\mathrm{a}}$ & $3.01 \pm 0.11^{\mathrm{b}}$ \\
\hline
\end{tabular}

Table 3 Pearson's correlation coefficients between the variables.

\begin{tabular}{l|ccc}
\hline \multicolumn{1}{c|}{ Variables } & IC50 inhibition values & Total Phenolics & Total Flavonoids \\
\hline Total Phenolics & $0.887^{*}$ & & \\
Total Flavonoids & $0.883^{*}$ & $0.999^{*}$ & $-0.987^{*}$ \\
Condensed Tannins & $-0.848^{*}$ & $-0.981^{*}$ & \\
\hline
\end{tabular}

*Correlation is significant at the 0.05 level. 
Pearson's correlation coefficient analysis was performed to determine the relationship between $\mathrm{IC}_{50}$ inhibition values and total phenolic, flavonoid and condensed tannin contents (Table 3). Positive significant correlations $(\mathrm{P}<0.05)$ were found between $\mathrm{IC}_{50}$ inhibition value and total phenolic content $(\mathrm{r}=0.887)$. In agreement with previous studies (Zubia et al., 2007; Goiris et al., 2012; Ak and Türker, 2018), there was a strong correlation between antioxidant activity and phenolic content of two algae. According to Pearson's correlation coefficient analysis, a strong positive relationship was found between $\mathrm{IC}_{50}$ inhibition value and total flavonoid content $(\mathrm{r}=0.883)$. There was a negative correlation between $\mathrm{IC}_{50}$ inhibition value and condensed tannin content $(\mathrm{r}=-0.848)$. Our results show similarities with Ak and Türker (2018). According to Piluzza and Bullitta (2011), the antioxidant activity of photosynthetic organisms not only dependent on the concentration but also depends on the structure and the interaction between the antioxidants. This can explain why $U$. rigida and $A$. platensis which had different phenolic, flavonoid, and condensed tannin content, exhibited a similar antioxidant activity.

\section{Conclusions}

Algae are good sources of polyphenols such as phenols, flavonoids, carotenoids, and tannins. In the present study, the antioxidant activity of $U$. rigida and A. platensis was evaluated. The results clearly showed that tested algae have high antioxidant activity with low $\mathrm{IC}_{50}$ inhibition values. We conclude that the main contributors to antioxidant activity these two algae according to the significant correlation between $\mathrm{IC}_{50}$ inhibition values and total phenolic and flavonoid contents. The results of the present study are promising as algal polyphenolic compounds are effective antioxidants and they could have potential in food applications. These results also show that polyphenolic compounds present in these algae extracts would be capable of functioning as free radical scavengers. Our findings appear useful in leading to further study in the identification and characterization of specific compounds responsible for antioxidant activities in these algae species.

\section{References}

Ak I, Türker G. 2018. Antioxidant properties and phytochemicals of three brown macroalgae from the Dardanelles (Çanakkale) Strait. Agricultural Science and Technology. 10(4): 354-357. DOI: $10.15547 /$ ast.2018.04.065

Ak I, Öztaşkent C, Özüdoğru Y, Göksan T. 2015. Effect of sodium acetate and sodium nitrate on biochemical composition of green algae Ulva rigida. Aquacult Int. 23(1):1-11. DOI: 10.1007/s10499-014-9793-3.

Alenisan MA, Alqattan HH, Tolbah LS, Shori AB. 2017. Antioxidant properties of dairy products fortified with natural additives: A review. Journal of the Association of Arab Universities for Basic and Applied Sciences. 24:101-106. DOI: 10.1016/j.jaubas.2017.05.001

Brand-Williams W, Cuvelier ME, Berset C. 1995. Use of a free radical method to evaluate antioxidant activity. LWT - Food Sci. Technol., 28; 25-30.

Choe E. 2017. Effect and mechanisms of minor compounds in oil on lipid oxidation. Ed. Akoh C.C., In: Food Lipids: Chemistry, Nutrition, and Biotechnology. CRC Press.Boca Raton, Fourth Edition. ISBN: 978-1-4987-4485-0 pp:567-590.
Cox S, Abu-Ghannam N, Gupta S, 2010. An assessment of the antioxidant and antimicrobial activity of six species of edible Irish seaweeds. International Food Research Journal, 17, 205 -220 .

Djeridane A, Yousfi M, Nadjemi B, Boutassouna D, Stocher, Vidal N. 2006. Antioxidant activity of some Algerian medicinal plants extracts containing phenolic compounds. Food Chem. 97:654-660. DOI: 10.1016/j.foodchem. 2005.04.028

Duan XJ, Zhang WW, Li XM, Wang BG. 2006. Evaluation of antioxidant property of extract and fractions obtained from a red alga, Polysiphonia urceolata. Food Chemistry 95: 37-43. DOI: 10.1016/j.foodchem.2004.12.015

Fleurence J. 1999. Seaweed proteins: biochemical, nutritional aspects and potential uses. Trends Food Sci Technol 10(1):25-28. DOI: 10.1016/S0924-2244(99)00015-1

Gargouri M, Magne C, El Feki A. 2016. Hyperglycemia, oxidative stress, liver damage and dysfunction in alloxaninduced diabetic rat are prevented by Spirulina supplementation. Nutr Res 36(11):1255-1268. DOI: 10.1016/j.nutres.2016.09.011.

Goiris K, Muylaert K, Frayee I, Foubert I, De Brabanter J, De Cooman L. 2012. Antioxidant potential of microalgae in relation to their phenolic and carotenoid content. J Appl Pyhcol 24:1477-1486. DOI: 10.1007/s10811-012-9804-6

Gordillo FJL, Jiménez C, Goutx M, Niell X. 2001. Effects of $\mathrm{CO}_{2}$ and nitrogen supply on the biochemical composition of Ulva rigida with special emphasis on lipid class analysis. J Plant Physiol 158(3):367-373. DOI: 10.1078/0176-1617-00209

Guiry MD and Guiry GM, 2019. AlgaeBase. World-wide electronic publication, National University of Ireland, Galway. http://www.algaebase.org; searched on 19 February 2019.

Ismail GA. 2017. Biochemical composition of some Egyptian seaweeds with potent nutritive and antioxidant properties. Food Science and Technology, 37(2), 294 - 302. DOI: 10.1590/1678-457X.20316

Jensen GS, Attridge VL, Beaman JL, Guthrie J, Ehmann A, Benson KF. 2015. Antioxidant and Anti-Inflammatory Properties of an Aqueous Cyanophyta Extract Derived from Arthrospira platensis: Contribution to Bioactivities by the Non-Phycocyanin Aqueous Fraction. Med Food 18 (5):535541. DOI: 10.1089/jmf.2014.0083

Jerez-Martel I, Garcia-Poza S, Rodriguez-Martel G, Rico M, Afonso-Olivares C, Gomez-Pinchetti JL. 2017. Phenolic profile and antioxidant activity of crude extracts from microalgae and cyanobacteria strains. Hindawi Journal of Food Quality. 2017:1-8. DOI: 10.1155/2017/2924508

Kazir M, Abuhassira Y, Robin A, Nahor O, Luo J, Israel A, Golberg A, Livney YD. 2019. Extraction of proteins from two marine macroalgae Ulva sp. And Gracilaria sp., for food application, and evaluating digestibility, amino acid composition and antioxidant properties of the protein concentrates. Food Hydrocolloids. 87: 194 - 203. DOI: 10.1016/j.foodhyd.2018.07.047

Klejdus B, Kopecky J, Benêsová L, Vacek J. 2009. Solid phase/supercritical-fluid extraction for liquid chromatography of phenolic compounds in freshwater microalgae and selected cyanobacterial species. Journal of Chromatography A, 1216(5):763-771. DOI: 10.1016/j.chroma. 2008.11.096

Kumar CS, Ganesan P, Suresh PV, Bhaskar N. 2008. Seaweeds as a source of nutritionally beneficial compounds, a review. Journal of Food Science Technology 45:1-13.

Kumar J, Khan A, Mandotora SK, Dhar P, Tayade AB, Verma S, Toppo K, Arora R, Upreti DK, Chaurasie OP. 2019. Nutraceutical profile and evidence of alleviation of oxidative stress by Spirogyra particles (Muell.) Cleve inhabiting the high altitude Trans-Himalayan Region. Scientific Reports 9:4091. DOI: 10.1038/s41598-018-35595-x 
Liu JG, Hou CW, Lee SY, Chuang Y, Lin CC. 2011. Antioxidant effects and UVB protective activity of Spirulina (Arthrospira platensis) products fermented with lactic acid bacteria. Process Biochemistry. 46(7): 1405-1410. DOI: 10.1016 /j.procbio.2011.03.010

Manach C, Scalbert A, Morand C, Rémésy C, Jiménez L. 2004. Polyphenols: Food sources and bioavailability. Am. J. Clin. Nutr. 79:727-747. DOI: 10.1093/ajcn/79.5.727

Matanjun P, Suhaila M, Mohamed MN, Kharidah M, and Hwee MC. 2008. Antioxidant activities and phenolics content of eight species of seaweeds from north Borneo. Journal of Applied Phycology, 367: 1573-5176. DOI: 10.1007/s10811007-9264-6

Mierziak J, Kostyn K, Kulma A. 2014. Flavonoids as Important Molecules of Plant Interactions with the Environment. Molecules. 19(10): 16240-16265. DOI: 10.3390 /molecules191016240

Mueller-Harvey I. 2006. Unraveling the conundrum of tannins in animal nutrition and health. Journal of the Science of Food and Agriculture, 86(13): 2010-2037.DOI: 10.1002/jsfa.2577

Piluzza G, Bullitta S. 2011.Correlations between phenolic content and antioxidant properties in twenty-four plant species of traditional ethnoveterinary use in Mediterranean area. Pharmaceutical Biology, 49:240-247. DOI: 10.3109 /13880209.2010.501083

Plaza M, Herrero M, Alejandro Cifuentes, E. Ibáñez, 2009. Innovative natural functional ingredients from microalgae. J. Agric. Food Chem. 57(16):7159-7170. DOI: 10.1021/jf901070g

Peña-Rodríguez A, Mawhinney TP, Ricque-Marie D, CruzSuárez LE. 2011. Chemical composition of cultivated seaweed Ulva clathrata (Roth) C. Agardh. Food Chem 129(2):491-498. DOI: 10.1016/j.foodchem.2011.04.104

Pisoschi AM, Pop A. 2015. The role of antioxidants in the chemistry of oxidative stress: A review. European Journal of Medicinal Chemistry. 97:55-74. DOI: 10.1016 /j.ejmech.2015.04.040

Price ML, Vanscoyoc S, Butler LG. 1978. Critical evaluation of Vanillin reaction as an assay for tannin in sorghum grain. J. Agric. Food Chem. 26 (5):1214-1218. DOI: 10.1021 /jf60219a031

Quettier-Deleu C, Gressier B, Vasseur J, Dine T, Brunet J, Luyck M, Cazin M, Cazin JC, Bailleul F, Trotin F. 2000. Phenolic compounds and antioxidant activities of buckwheat (Fagopyrum esculentum Moench) hulls and flour. J. Ethnopharmacol. 72(1-2):35-40. DOI: 10.1016/S0378-8741 (00)00196-3
Rodrigo R, Bosco C. 2006. Oxidative stress and protective effects of polyphenols: comparative studies in human and rodent kidney. A review. Comp Biochem Physiol C Toxicol Pharmacol. 142(3-4):317-27. DOI: 10.1016/j.cbpc. 2005.11.002

Shalaby EA. 2015. Algae as a Natural Source of Antioxidant Active Compounds. Plants as a Source of Natural Antioxidants In: Ed. Dubey NK. CAB International. Oxfordshire. ISBN: 978-1-78064-266-6. pp: 129-147.

Sindhi V, Gupta V, Sharma K, Bhatnagar S, Kumari R, Dhaka N. 2013. Potential applications of antioxidants - A review. Journal of Pharmacy Research. 7: 828 - 835. DOI: 10.1016 /j.jopr.2013.10.001

Trigui M, Gasmi L, Zouari I, Tounsi S. 2013. Seasonal variation in phenolic composition, antibacterial and antioxidant activities of Ulva rigida (Chlorophyta) and assessment of antiacetylcholinesterase potential. J Appl Phycol 25:319-328. DOI: $10.1007 / \mathrm{s} 10811-012-9866-5$

Vasconcelos JB, de Vasconcelos ERTPP, Urrea-Victoria V, Bezerra PS, Reis TNV, Cocentino ALM, Navarro DMAF, Chow F, Areces AJ, Fuji MT. 2018. Antioxidant activity of three seaweeds from tropical reefs of Brazil: potential sources for bioprospecting. Journal of Applied Phycology. DOI: 10.1007/s10811-018-1556-5

Vonshak A. 1997. Spirulina platensis (Arthrospira): physiology, cell biology and biotechnology (1st ed.). London: Taylor and Francis Ltd. ISBN: 978-0-7484-0674-6

Wang L, Pan B, Sheng J, Xu J, Hu Q. 2007. Antioxidant activity of Spirulina platensis extracts by supercritical carbon dioxide extraction. Food Chemistry, 105, 36-41. DOI: 10.1016/j.foodchem.2007.03.054

Yuan YV, Carrington MF, Walsh NA. 2005. Extracts from dulse (Palmaria palmata) are effective antioxidants and inhibitors of cell proliferation in vitro. Food and Chemical Toxicology 43: 1073-1081.DOI. 10.1016/j.fct.2005.02.012

Zarrouk, C., 1966. Contribution à l'étude d'une Cyanophycée. Influènce de Divers Facteurs Physiques et Chimiques sur la Croissance et la Photosynthèse de Spirulina maxima (Setch. et Gardner) Geitler, Paris, France, University of Paris.

Zubek S, Mielcarek S, Turnau K. 2012. Hypericin and pseudohypericin concentrations of a valuable medicinal plant Hypericum perforatum L. are enhanced by arbuscular mycorrhizal fungi. Mycorrhiza, 22(2): 149-156.DOI: 10.1007/s00572-011-0391-1

Zubia M, Robledo D, Frelie-Pelegrin Y. 2007. Antioxidant activities in tropical marine macroalgae from the Yucatan Peninsula, Mexico. J Appl Physiol, 19, 449 - 458. DOI: 10.1007/s10811-006-9152-5 